\title{
Newts with superpowers
}

\author{
by Kara Rosania
}

SCIENTIFIC NAME

Pleurodeles waltl

TAXONOMY

PHYLUM: Chordata

CLASS: Amphibia

ORDER: Urodela

FAMILY: Salamandridae

\section{Physical description}

Ribbed newts are stout-bodied salamanders with rough, gray-brown skin covered in irregular dark spots. On each side of the body there is a row of several orange, wart-like spots. Their broad heads are flat, with small eyes and moveable eyelids. Their tails are long (longer in males than females) with a narrow fin, perfectly adapted for swimming. They live in aquatic habitats with slowmoving, shallow water and abundant vegetation. Ribbed newts reach lengths of 7-12 in, with individuals from European populations reaching larger sizes than individuals from northern African populations.

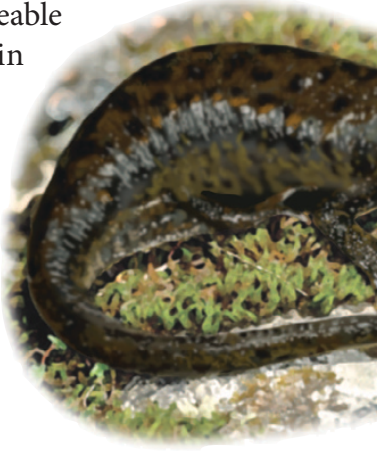

\section{Defense against predators}

Pleurodeles walt have been called several names: giant ribbed newt, Iberian or Spanish ribbed newt and sharp-ribbed newt. The last of these refers to its defense mechanism: when the ribbed newt becomes agitated or perceives a threat, it swings its ribs forward, increasing their angle to the spine by up to $50^{\circ}$. As it does this, the newt keeps the rest of its body still so that the tips of the newt's ribs penetrate through the skin wall, sticking outside its body. If a predator tries to bite the newt or pick it up using its mouth, the newt's ribs act like poisonous barbs, injecting a poisonous, milky substance secreted from its skin into the mouth of the predator. Because the secretion contains irritating toxins, it causes severe pain or possibly death to the predator, allowing the newt to go free ${ }^{1}$.

\section{Research résumé}

Even though the ribbed newt forces its bones through its skin every time it is attacked, this does not cause the newt any long-term harm $^{1}$. This is because newts are able to reconstruct damaged tissue after injury ${ }^{2}$. In addition to their skin, they can regenerate lost limbs and optical, brain, spinal cord, intestine and heart tissues. Ribbed newts have therefore been used as a unique experimental model of regeneration. The study of genetic mechanisms underlying regeneration was impeded until recently because of difficulties with breeding some newt species in the laboratory. $P$. walt have been ideal for this research because they spawn fertilized eggs yearround in the laboratory and lay more than 150 eggs every 2 weeks. A recent study established methods for artificial insemination and transgenesis using ribbed newts to enhance the species' use in such molecular genetic studies ${ }^{2}$.

The ease of breeding $P$. walt has also been useful for spaceflight experiments. To understand the effects of spaceflight conditions, including confinement, microgravity, biomechanical stresses imposed by hypergravity forces during launch and landing, increased radiation and disruption of the circadian rhythm ${ }^{3}$, ribbed newts have been raised at the International Space Station and compared to newts raised on Earth and to newts raised with simulated space conditions $s^{3-5}$. The ribbed newt is particularly useful for studies of immunity because it shares the primary elements of the adaptive immune system with humans ${ }^{3}$. Studies using ribbed newts have demonstrated immune system deregulation during and immediately following spaceflight, which could compromise defenses against infection ${ }^{3-5}$. Experiments to determine the effects of spaceflight on development have also used ribbed newts, owing to their slow development, the large size of their cells, their diploid genomes and the ability to raise them in closed water containers with limited food ${ }^{6,7}$.

1. Heiss, E., Natchev, N., Rabanser, A., Weisgram, J. \& Hilgers, H. Three types of cutaneous glands in the skin of the salamandrid Pleurodeles waltl. A histological and ultrastructural study. J. Morphol. 270, 892-902 (2009).

2. Hayashi T. et al. Molecular genetic system for regenerative studies using newts. Dev. Growth Differ. 55, 229-236 (2013).

3. Schenten, V., Guéguinou, N., Baatout, S. \& Frippiat, J.P. Modulation of Pleurodeles waltl DNA polymerase $m u$ expression by extreme conditions encountered during spaceflight. PLoS One 8, e69647 (2013).

4. Frippiat, J.P. Contribution of the urodele amphibian Pleurodeles walt to the analysis of spaceflight-associated immune system deregulation. Mol. Immunol. 56, 434-441 (2013).

5. Huin-Schohn, C. et al. Gravity changes during animal development affect IgM heavy-chain transcription and probably lymphopoiesis. FASEB J. 27, 333-341 (2013).

6. Duprat, A.M. What mechanisms drive neural induction and neural determination in urodeles? Int. J. Dev. Biol. 40, 745-754 (1996).

7. Dournon, C. Developmental biology of urodele amphibians in microgravity conditions. Adv. Space Biol. Med. 9, 101-131 (2003). 